\title{
Komposisi Kala
}

\author{
M. Yoga Supeno ${ }^{1}$ \\ Jurusan Etnomusikologi, Fakultas Seni Pertunjukan, Institut Seni Indonesia Yogyakarta.
}

\begin{abstract}
ABSTRAK
Komposisi ini merupakan representasi dari sebuah perubahan pola pikir manusia yang dari zaman ke zaman selalu bergerak maju. Kala yang berarti waktu merupakan refleksi garis panjang sejarah dari terbentuk dan berkembangnya peradaban pada masa lampau. Perkembangan waktu tersebut kemudian dijadikan tiga bagian waktu (prasejarah, sejarah, modern) untuk menggambarkan perubahan-perubahan yang terjadi pada setiap waktu khususnya di provinsi Lampung. Secara garis besar penyajian Kala adalah memadukan instrumen musik Barat dan etnis yang sebagian besar instrumen terdiri dari instrumen perkusi seperti marimba, vibraphone, xylophone, chime, drumset, bonang Sunda, cetik, rebana serta ditambah dengan instrumen melodis seperti akodion, biola, gambus, dan electric bass. Motif dan teknik permainan merupakan salah satu penggambaran dari ketiga zaman tersebut yang menghasilkan suasana liar, agamis, dan modernisasi dan bernuansa etnis Lampung dan Melayu.
\end{abstract}

Kata kunci: Kala/waktu, sejarah Lampung.

ABSTRACT

The Kala Music Composition. This composition is a representation of a human mindset change which is always moving forward from time to time. Kala which means time is a reflection of a history starting from when the history and the civilization were formed and developed in the past. Then, the time development is divided into a three-part time (prehistory, history, modern) to describe the changes that may occur at any time, especially in the province of Lampung. Basically, the presentation of Kala is combining the western and ethnic musical instruments that most of the them consist of percussion instruments such as marimba, vibraphone, xylophone, chime, drum set, bonang Sunda, cetik, tambourines, and melodic instruments such as accordion, violin, harp, and electric bass. The motive and technique of the performance is one of the three depictions of the era that produces the wild and religious atmosphere, modernization, and that is nuanced by Lampung and Malay ethnics.

Keywords: Kala Itime, history of Lampung

\section{Pendahuluan}

Konsep dasar karya seni dalm tulisan ini adalah tentang sejarah daerah Lampung lebih tepatnya peradaban manusia dari zaman prasejarah, zaman sejarah, dan zaman modern sampai saat ini. Konsep tersebut terinspirasi dari sebuah rangsangan ketika melihat sebuah topeng manusia purba, kita pasti sudah tahu dengan sendirinya bagaimana manusia purba pada zamannya tersebut; liar, belum mengenal tulisan, hidup berpindahpindah, sangat tergantung dengan alam, belum memiliki akal pikiran yang sempurna, tetapi di sisi lain manusia purba memiliki kekompakan dalam setiap kelompoknya khususnya di provinsi Lampung.

Zaman prasejarah adalah zaman dimana manusia belum mengenal tulisan, dan hidup secara berkelompok dan berpindah-pindah.
Untuk daerah Lampung batas antara zaman prasejarah dan zaman sejarah itu masih merupakan problem, terutama mengenai batas waktunya yang pasti. Tentang adanya masa prasejarah di Lampung diperkuat oleh buktibukti dengan diketemukannya prasasti dan peninggalan purbakala yang tersebar diseluruh daerah. Penemuan-penemuan situs purbakala itu ada yang ditemukan secara sengaja atau tidak sengaja. Corak peninggalan prasejarah di Lampung mempunyai ciri yang sangat berlainan sifatnya bila dibandingkan dengan peninggalan prasejarah di daerah lainnya di Indonesia. Suatu contoh misalnya (1) Megalitik di Lampung banyak bercorak statis dan mungkin sekali megalitik yang bercorak dinamis adalah merupakan lanjutan/ sambungan dari megalitik di Pesemah yang luas itu. (2) Goresan-goresan pada batu yang sering oleh penduduk disebut batu besurat, pada hakekatnya

1 Alamat Korespondensi: Prodi Etnomusikologi, ISI Yogyakarta. Jalan Parangtritis Km. 6,5 Sewon Yogyakarta - 55001. HP. 0857671 4600.E-mail: yogasupeno@yahoo.com 
adalah goresan yang belum diketahui makna dan artinya dan terdapat pada beberapa tempat situs megalitik. Sejenis ini juga ditemukan di Palu (Sulawesi Tengah). (3) Pemukiman manusia purbakala pada umumnya tidak terdapat di gua atau pantai seperti daerah lainnya di Indonesia, tetapi pada bukit yang dikelilingi parit atau sebidang tanah yag dikelilingi pematang tinggi yang merupakan perbentengan terhadap binatang buas (Bukri, 1997/1998:2).

Jika dilihat dari tempat tinggal mereka, maka dapat ditarik kesimpulan bahwa manusia purba pada zaman tersebut hidupnya bercocok tanam, mungkin sebelum mereka menetap kehidupannya berburu di hutan, ternyata dari peninggalan senjata mereka berupa tombak dan pedang, rumahrumah yang mereka dirikan di atas tonggak besar (rumah panggung) menunjukkan bahwa mereka masih perlu bertahan dari serangan binatang buas (Bukri, 1997/1998:13).

Sistem kepercayaan mereka termasuk animisme dan dinamisme, adanya dolmen, menhir, serta kepercayaan lain terhadap kekuatan gaib (magi hitam, magi putih) azimat dan lain-lain, menunjukkan pengaruh animisme dan dinamisme itu. Perkembangan seni dan budaya pada masa ini merupakan perkembangan awal seperti yang didapati pada upacara-upacara kesukuan. Berdasarkan paparan di atas, dapat ditarik kesimpulan bahwa perkembangan musik di Lampung pada zaman prasejarah adalah sangat sederhana dan kebanyakan hanya menggunakan alat musik yang terbuat dari kayu dan kulit hewan saja. Berdasarkan penjelasan di atas maka pengaplikasian terhadap karya ini berupa gerak dari para pemain (pemusik) yang menirukan tingkah laku manusia purba saat berpesta setelah mendapatkan hasil buruannya. Para pemain (pemusik) menghentakan kaki kelantai sambil memukul properti bambu yang dibuat menyerupai rumbai-rumbai suku primitif. Permainan pola ritmis sangat dominan pada bagian ini sambil melantunkan vokal umpello apello. Dalam karya ini vokal umpello apello tercipta karena penulis tidak mengetahui jelas bahasa manusia purba pada umumnya.

Zaman sejarah adalah zaman yang dianggap permulaan dari sejarah Indonesia. Pada zaman ini sudah ditemukan sumber tertulis yang membedakan dengan zaman sebelumnya yaitu zaman prasejarah. Berdasarkan penjelasan tersebut penulis mengaplikasikannya kedalam sebuah komposisi musik etnis berupa pola pemainan cetik yang mewakili agama Hindu dan pola permainan biola, gambus, akordion yang mewakili zaman Islam. Semua motif tersebut dipadukan sehingga membentuk satu kesatuan yang utuh berlatar belakang instrumen marimba, vibraphone, xylophone, chime, electric bass, dan drumset.

Zaman kemerdekaan atau zaman modern sampai saat ini adalah dimana manusia banyak mengalami perubahan dan sudah mengenal teknologi. Perkembangan revolusi industri di Eropa pada abad ke-19 mulai mempengaruhi keadaan di Indonesia. Memasuki abad ke-20 keadaan Lampung khusunya di kota Bandar Lampung sudah mulai berubah, muncul mobilmobil sebagai gejala modern serta muncul teknologi-teknologi hingga pada masa sekarang ini. Penduduk yang menghuni kota Bandar Lampung ini juga mayoritas pendatang/transmigrasi dan hanya sebagian kecil masyarakat yang memang asli suku Lampung.

Bahasa sehari-hariyang digunakan selain bahasa daerah dari mana mereka berasal, juga digunakan bahasa Indonesia dalam pergaulan tetapi apabila dalam rumah tangga masih juga digunakan bahasa daerah setempat. Tulisan yang digunakan sudah jarang sekali memakai tulisan Lampung (Aksara Lampung), hanya generasi tua saja yang masih dapat menggunakan tulisan Lampung tersebut. Semua hal tersebut juga mempengaruhi kesenian tradisi yang ada di kota Bandar Lampung terutama musik etnis dikalangan generasi muda sampai saat ini. Perkembangan musik etnis sangatlah sedikit terutama bagi kaum pemuda dan pemudinya, mereka lebih cenderung mengenal musik barat dan musik band. Berdasarkan penjelasan tersebut penulis mengaplikasikannya ke dalam sebuah komposisi musik etnis yaitu dengan cara memasukan motif-motif band seperti swing jazz, jungle, rock dan kemudian dipadukan dengan instrumen-instrumen etnis pada adegan ini.

Berdasarkan hal tersebut di atas, tentang garis waktu dalam sejarah Lampung, penulis akan mewujudkannya dalam sebuah karya tugas akhir yang nantinya akan diberi judul "Kala". Kala sendiri berarti waktu atau dari masa ke masa, mewakili keseluruhan ide gagasan penulis 
tentang latar belakang sejarah Lampung dimana perubahan dan perkembangan zaman terjadi dengan sendirinya seiring perjalanan waktu.

Secara konseptual karya ini dilandasi dengan mengulas sejarah yang ada di Provinsi Lampung yang nantinya akan dijadikan tiga zaman. Pada karya ini, peradaban akan dijadikan latar belakang untuk mewakili ketiga zaman tersebut. Hingga pada akhirnya karya yang diciptakan mampu menyampaikan informasi yang dapat diapresiasi oleh penonton.

\section{Rancangan Bentuk Garapan}

\section{Musikal}

Garapan ini mengacu dan berpijak kepada etnis Lampung. Alasan penulis selalu mengacu dan berpijak kepada etnis Lampung adalah karena latar belakang penulis yang lahir dan dibesarkan di Provinsi Lampung, ingin mengangkat seni dan budaya yang ada di Lampung khususnya seni musik etnis Lampung, serta ingin membuktikan kepada generasi-generasi muda zaman sekarang khususnya di kota Bandar Lampung, bahwa peranan musik etnis sangat penting dan tidak kalah dengan musik-musik band atau pop pada zaman modern saat ini.

Secara garis besar, penyajian karya ini dibuat dalam tiga bagian dengan durasi sekitar 23 menit (bagian I kurang lebih 8 menit, bagian II kurang lebih 10, bagian II kurang lebih 5 menit). Ketiga bagian tersebut bercerita tentang zaman prasejarah, zaman sejarah, dan zaman modern sampai saat ini, menggunakan peradaban yang mewakili zamannya masing-masing sebagai latar belakangnya.

\section{Non Musikal}

\section{a. Tata Teknik Panggung}

tetapi dalam komposisi Kala ini tempat yang dipakai untuk melangsungkan pementasannya adalah Stage atau Proscenium, karena lebih mengandalkan akustik di dalam ruangan. Panggung proscenium dilengkapi dengan properti berupa bebatuan yang akan diletakan di pinggirpinggir belakang proscenium. Properti tersebut dimaksudkan untuk memperkuat konsep garapan dan kebutuhan komposisi.

\section{b. Tata Cahaya}

Pada bagian awal karya ini (zaman purba) warna cahaya yang digunakan adalah warna merah. Warna merah mencerminkan sifat dan emosi manusia yaitu: cinta, nafsu, kekuatan, berani, primitif, menarik, bahaya, dosa, pengorbanan, vitalitas (Darmaprawira, 2002:37). Pada karya ini warna merah dicampur dengan warna kuning adalah ingin menghasilkan suasan kepurbaan pada zaman dahulu. Pada bagian kedua karya ini (zaman agama) warna cahaya yang digunakan adalah warna ungu dan biru. Warna ungu memiliki karakteristik sejuk, negatif, mundur, hampir sama dengan biru tetapi lebih tenggelam dan khidmat, mempunyai karakter murung dan menyerah. Pada bagian III atau bagian akhir karya ini (zaman modern) warna cahaya yang digunakan adalah warna kuning. Warna kuning melambangkan keceriaan dan kelincahan. Pada adegan terakhir ini harapan penulis adalah ingin memunculkan suasana modern.

\section{c. Tata Rias dan Busana}

Tata rias yang digunakan disesuaikan dengan konsep komposisi Kala, yaitu menggunakan tata rias yang lebih natural dan hanya menggunakan bedak saja ditambah dengan garis hitam yang ada pada pipi, hidung, dan dahi. Garis hitam tersebut adalah penggambaran dari perjalanan waktu. Busana dalam garapan ini dirancang untuk memenuhi konsep komposisi Kala yaitu celana panjang yang berukuran tidak terlalu dari pinggul sampai betis, dan mengecil pada bagian mata kaki serta ditambahkan penutup kepala yang dibuat menyerupai kain sorban yang biasa dipakai oleh pemuka adat agama Islam.

Warna dari kostum tersebut adalah bebatuan yang menyesuaikan dengan setting panggung yaitu warna abu-abu. Properti yang digunakan dalam celana adalah bambu menyerupai cetik dan digantung dipinggang, sehingga menyerupai penutup celana yang biasa dipakai suku-suku primitif. Properti bambu yang dipakai pada celana dapat menghasilkan bunyi apabila pemusik bergerak.

Pada komposisi Kala ini properti bambu tersebut dipukul dan ditata menjadi sebuah komposisi bunyi ritmis yang dinamis. Pada komposisi kala ini seluruh pendukung tidak 
mengenakan baju (telanjang dada) ditambah dengan body painting yang motif merupakan modifikasi dari motif kain tapis Lampung serta hiasan akar-akar yang melilit dikedua lengan para pemusik. Kain Tapis Lampung adalah pakaian adat wanita suku Lampung yang berbentuk kain sarung terbuat dari tenun benang kapas dengan motif atau hiasan bahas sugi, benang perak atau benang emas dengan sistem sulam Lampung.

\section{d. Sound System}

Sound system sangatlah penting untuk mendukung keberhasilan sebuah karya seni, terutama karya musik. Sound System yang digunakan dalam garapan ini berfungsi untuk memperkuat atau memperjelas motif-motif permainan yang dihasilkan oleh pendukung. Sound System juga berfungsi untuk penyeimbang suara yang dihasilkan terutama instrumen yang berkarakter soft (lembut) agar terdengar jelas oleh penonton. Jenis microphone yang digunakan yaitu shure 57, 58, dan clip on.

\section{Proses Penciptaan}

\section{Rangsangan Awal}

Suatu rangsang dapat didefinisikan sebagai sesuatu yang membangkitkan fikir, atau semangat, atau mendorong kegiatan dan rangsang membentuk denyut dasar di belakang dan selanjutnya membentuk struktur (Smith, 1985:20). Komposisi musik Kala bermula dari rangsangan awal terhadap sebuah topeng manusia purba. Topeng manusia purba tersebut kemudian dijadikan inspirasi untuk merefleksikan garis waktu sejarah dari terbentuk dan berkembangnya peradaban pada masa lampau. Perkembangan waktu tersebut kemudian dijadikan tiga bagian waktu untuk menggambarkan perubahanperubahan yang terjadi pada setiap waktu. Adapun pembagian waktu yang dimaksud, adalah; zaman pra sejarah, zaman sejarah dan zaman sekarang.

\section{Inspirasi (Pemunculan Ide)}

Setelah melewati tahap rangsangan awal, hasil rangsangan tersebut diwujudkan dalam sebuah ide cipta. Penulis terinspirasi untuk memusikalisasikannya menjadi sebuah garapan musik etnis yang berlatar belakang dari sejarah daerah Lampung.

\section{Eksplorasi}

Eksplorasi termasuk berfikir, berimajinasi, merasakan dan merespons (Hawkins, 1990:27). Penulis melakukan eksplorasi vokal yang berhubungan dengan manusia purba tersebut. Vokal tersebut akan diolah menjadi vokal yang monotone tetapi tidak membosankan bagi yang mendengarkannya. Instrumen yang penulis gunakan adalah kebanyakan instrumen perkusi baik itu perkusi etnis maupun modern. Penulis ingin menekankan suasana-suasana kepurbaan serta masuknya ajaran-ajaran agama dan didukung dengan instrumen musik barat seperti kombo band untuk menekankan suasana modern.

Beberapa instrumen tersebut di atas dipilih didasarkan atas keinginan untuk mencapai tingkatan suasana yaitu suasana purba, agama, dan modern. Setelah instrumen sudah ditentukan, penulis mulai mencari motif-motif ritmis dan melodis secara bertahap untuk memperbanyak perbendaharaan motif yang nantinya akan penulis gunakan pada komposisi ini. Pencarian motif ritmis dan melodi tersebut dilakukan setiap hari dan dicoba sebelum latihan bersama para pendukung.

Berikut pengolah ritmis pada bagian awal komposisi ini.

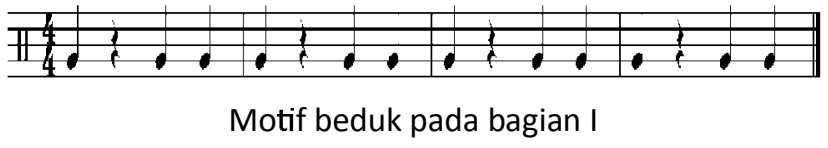

Diolah menggunakan teknik filler (isian) menjadi:

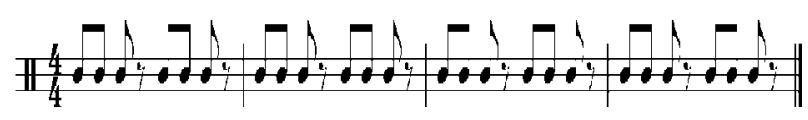

Pengolahan filler (isian) seperti contoh di atas dimaksudkan untuk memberi hiasan-hiasan ritmis supaya terkesan tidak kosong. Motif dari hasil pengolahan filler akan digunakan untuk memberikan variasi-variasi pada penggarapan ritmis. Motif tersebut akan sangat terasa jika dilakukan secara unisono. Contoh lain dari pengolahan motif diantaranya menggunakan teknik sekuens (pengulangan)

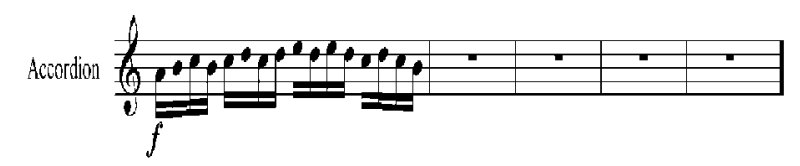




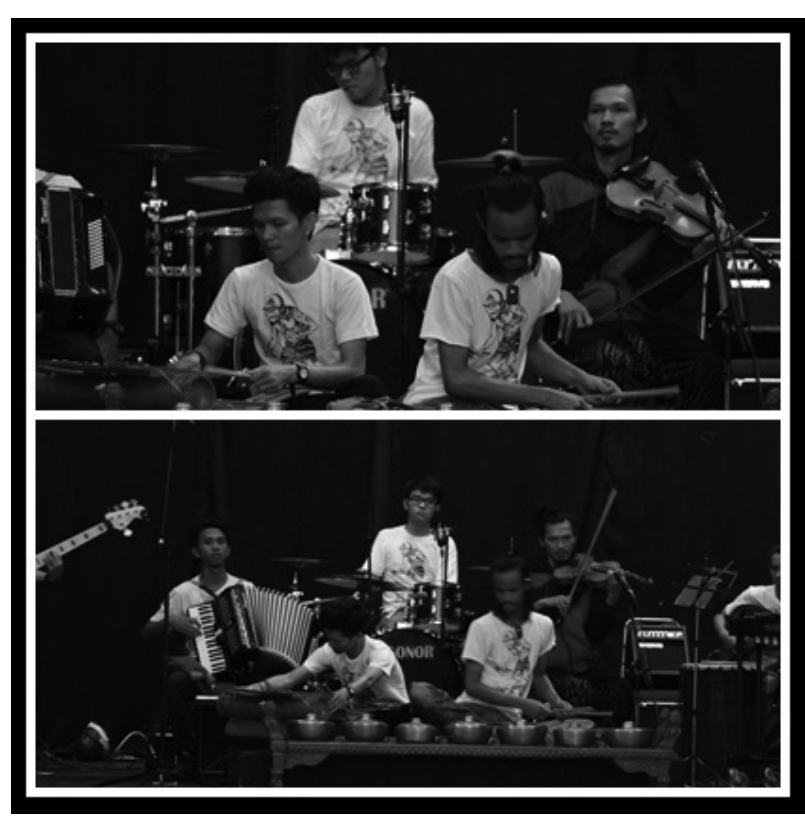

Gambar I. Proses eksplorasi komposisi Kala

(Foto: M.Yoga Supeno, 2012)

\section{Improvisasi}

Improvisasi memberikan kesempatan yang lebih besar bagi imajinasi, seleksi, dan mencipta dari eksplorasi. Metode ini merupakan proses pencarian teknik-teknik permainan ataupun pengembangan tanpa terkonsep sebelumnya, semua terjadi secara spontanitas dan dilakukan secara berulang-ulang sampai menemukan bentuk yang diinginkan. Proses ini dilakukan dengan cara melihat dan mendengarkan kembali rekaman hasil latihan, kemudian bagian yang kurang baik ditata dan diperbaharuhi kembali. Selain itu juga dilakukan improvisasi pada bagian-bagian dan waktu tertentu untuk meningkatkan keterampilan. Hal ini dilakukan untuk menjembatani pemikiran yang selalu berkembang dari waktu ke waktu, untuk mewujudkan sebuah komposisi yang optimal sesuai dengan konsep penciptaan yang telah dibangun. Suatu pengalaman improvisasi yang baik akan terasa bila disertai dengan timbulnya suatu kepuasan dan rasa yang benar-benar sulit diungkapkan dengan kata-kata. Dalam karya ini teknik improvisasi terdapat pada bagian II dan III. Pada bagian ke II teknik improvisasi dimainkan oleh instrumen, biola, gambus dan pada bagian III inmprovisasi dimaikan oleh instrumen, akordion, gambus, marimba, drumset, dan rebana.

\section{Pembentukan}

Musik yang berada dibagian awal menggunakan nuansa-nuansa kepurbaan atau primitif yang lebih cenderung pada suasana di alam sekitar. Pada bagian kedua ini dihadirkan nuansa atau suasana keagamaan yang diwakilkan dengan agama Hindu dan Islam. Pada bagian ketiga atau ending ditampilkan suasana modern khususnya yang ada di daerah kota Bandar Lampung. Dari keseluruhan pembentukan musik tersebut dilakukan selama proses latihan rutin bersama pendukung yang terjadwal seminggu tiga kali. Berikut adalah rancangan struktur bentuk musik pada karya Kala ini.

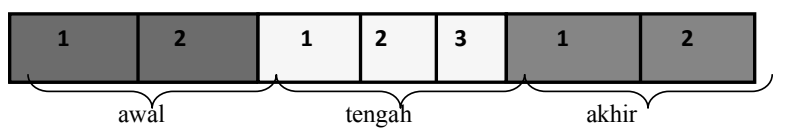

\section{Ulasan Komposisi}

\section{Ide dan Tema}

Pada kesempatan berkarya kali ini, penulis ingin menyampaikan sebuah konsep yang bersumber dari peradaban manusia dari waktu ke waktu. Peradaban yang dimaksud adalah peradaban manusia yang ada di Provinsi Lampung khususnya di Kota Bandar Lampung dari masa lampau hingga masa sekarang ini. Ide tersebut akan diungkapkan melalui karya komposisi musik etnis yang mengacu kepada etnis Lampung. Secara garis besar, garapan ini mengungkapkan tiga zaman yang ada di Provinsi Lampung yaitu zaman prasejarah (purba), zaman sejarah (Islam), dan zaman modern (sampai saat ini). Perubahan pola pikir manusia yang dari waktu ke waktu selalu maju, berkembang dan berjaya pada zamannya merupakan hal mendasar dan menjadi sebuah tema dalam karya Kala ini. Dengan kata lain, tema karya ini adalah perubahan.

Secara tekstual komposisi ini merupakan pengembangan dari komposisi yang pernah digarap sebelumnya yaitu pada mata kuliah Penciptaan Musik Etnis III yang berjudul Tribuana. Hal-hal yang dikembangkan menyangkut pada aspekaspek teknik permainan dan konteks budayanya.

\section{Bentuk}

Secara penyajiannya karya ini merupakan kemasan atau perpaduan karya musik instrumental (kombo band) dan vokal yang disajikan secara konser. Di samping pengolahan secara auditif, penyajian komposisi ini secara visual juga didukung dengan gerak-gerak tubuh pemain (pemusik). Bentuk dari karya ini secara keseluruhan adalah 

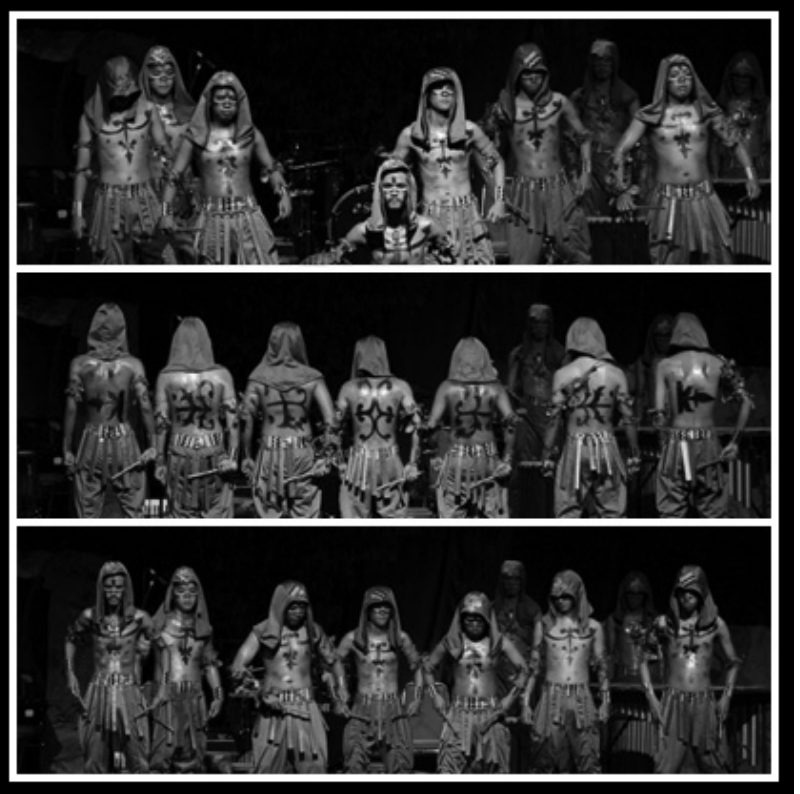

Gambar 2. Pementasan komposisi Kala. (Foto: M.Yoga Supeno, 2012)

harmoni dari nada-nada yang dihasilkan oleh masing-masing instrumennya yang sebagian besar instrumen perkusi. Penataan susunan musik sedikit demi sedikit ditata ulang dan dibersihkan agar jelas instrumen mana yang mendapat penonjolan, keras lirih, kecepatan bermain, dan durasi waktu yang dibutuhkan.

\section{Struktur}

Struktur komposisi Kala terdiri atas tiga bagian yaitu Bagian I, Bagian II, dan Bagian III. Masingmasing bagian tersebut dapat dijelaskan sebagai berikut.

\section{Bagian I}

Bagian I, karya ini menceritakan peradaban manusia purba yang sifatnya masih liar dan sangat bergantung kepada alam sekitar. Secara musikal pada bagian ini penulis membuat vokal monotone, kata-kata dari vokal tersebut adalah umpelo appelo yang akan diolah dengan pola-pola ritmis yang dinamis.

Ritmis beduk pada bagian I ini sangatlah mendukung suasana kepurbaan tersebut, ditambah dengan gerak musikal dari ke 7 pemusik sambil melantunkan vokal umpelo appelo yang diulangulang. Seluruh pemain (pemusik) bergerak sedemikian rupa yang menghasilkan pola-pola ritmis sambil memukul properti bambu pada kostum yang dikenakan serta melantunkan vokal umpelo Appelo tersebut. Suasana yang ditampilkan pada bagian I adalah suasana kepurbaan yang berbau alam sekitar. Tangga nada yang digunakan pada bagian ini adalah tangga nada minor dimulai dari akord Am dengan tempo sedang yang dimainkan dengan vokal dari seluruh pemain (pemusik). Dinamika yang ditekankan pada bagian ini adalah keras dan lembut

Motif pokok pada bagian ini adalah:

Instrumen beduk

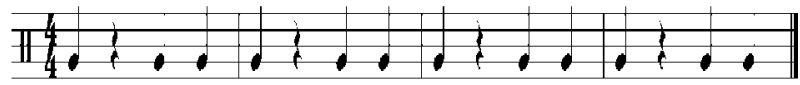

Dikembangkan dengan menggunakan teknik filler (isian)

Properti bambu

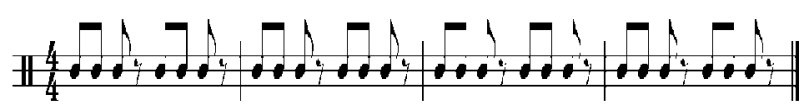

\section{Bagian II}

Pada bagian kedua ini diawali dengan permainan satu tempo, satu rasa, satu irama sejalan antara satu dengan yang lainnya yang dihiasi dengan motif-motif permainan tabuh tari daerah Lampung yang dimainkan dengan instrumen cetik. Sukat 7 dan sukat 6 mendominasi perpindahan tiap-tiap bagiannya.

Motif sukat 7 dan 6 tersebut adalah sebagai berikut.

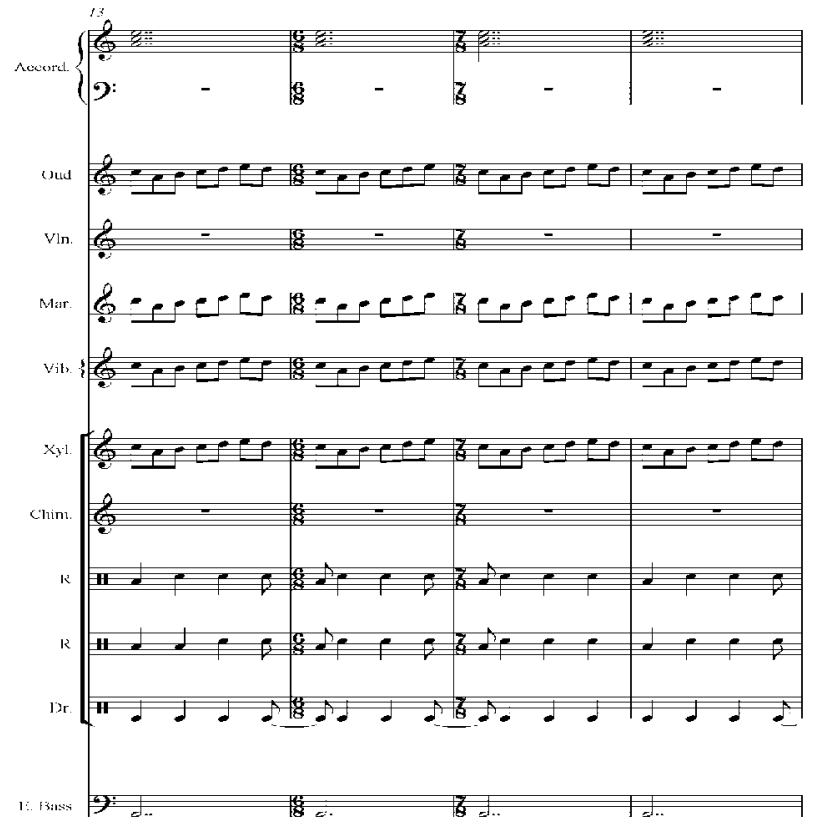

Keterangan: Sukat 7/8, 6/8, 7/8, 7/8 
Selanjutnya instrumen cetik memainkan motif tabuhan Lampung yaitu tabuh tari dan hanya diiringi dengan biola Melayu yang dimainkan secara improvisasi. Setelah itu instrumen perkusi seperti: marimba, chime, dan vibraphone ikut mengiringi tabuhan cetik tersebut sebagai latar belakang. Bagian ini juga ditambahkan vokal muayak Lampung yang diiringi dengan gambus. Adapun syair muayak yang penulis dapat dari salah seorang seniman Lampung tersebut adalah sebagai berikut.

"nabik pai jama nabi laju di tuhan kita tekhus diabli ouakhi sunyin sai tesengkurung dija haga wat sai tikaji lehot ni jak ulama adap wat dalih pekerti pakai kham di dunia Pegungan khukun iman khukun Islam tilapahi yakin kham satu tuhan ibada yado buktini balin kisah bubangan khepapa pai kham bu Tuhan khepa pai ham bu Nabi kiasan nawai badan kenyin makrifat buisimin".

Terjemahan syair di atas adalah:

"penghormatan kepada nabi, kehadirat tuhan kita, juga kepada sanak saudara, dan seluruh hadirin disini, bersama-sama mengkaji petuah alim ulama adat dan budi pekerti amalan di dunia, pegangan rukun iman dan rukun Islam dijalani dengan keyakinan Tuhan ibadah itulah buktinya, beralih pula kajian saya kepada kalian, bagaimana kita bertuhan dan bernabi serta kiasan menuntun badan agar makfirat kita berisi."

Pada bagian ini sub-tema yang diusung adalah zaman sejarah. Pada zaman ini suasana yang akan ditonjolkan adalah suasana keagamaan khususnya agama Islam dan Hindu. Instrumen yang menonjol pada bagian dua ini adalah permainan biola, gambus, akordion, rebana, dan vokal yang menghasilkan nafas Islami, sementara bonang Sunda dan cetik dimaksudkan sebagai interpretasi suasana Hindu. Instrumen pendukung lainnya seperti marimba, vibraphone, xylophone, chime, drumset, dan electric bass juga ikut bermain pada bagian ini, tetapi motif pola permainan dan intensitas suara lebih sederhana. Motif dan pola permainan instrumen tersebut dimaksudkan sebagai interpretasi zaman sejarah dan bukan dilihat dari segi instrumennya. Harapan penulis adalah ingin menonjolkan suasana khusuknya saat kita beribadah. Setelah mencapai puncak dari peribadahan tersebut setiap manusia pastilah merasakan ketenangan dan kenyaman batin. Dalam garapan ini ketenangan dan kenyamanan tersebut digambarkan dengan motif joget Melayu yang mengusung sukat $3 / 4$. Pada bagian ini tangga nada yang mainkan menggunakan tangga nada minor akord Am dengan tempo sedang menekankan dimamika keras dan lembut. Pada motif joget ini penulis meggunakan teknik repetisi (pengulangan). Pada bagian motif joget ini terdiri dari kalimat tanya dan kalimat jawab dengan menggunakan teknik repetisi (pengulangan).

Kalimat tanya:

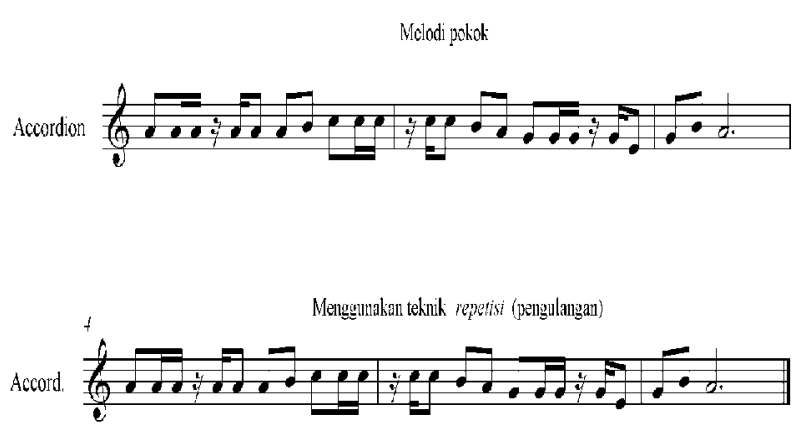

Kalimat jawab:
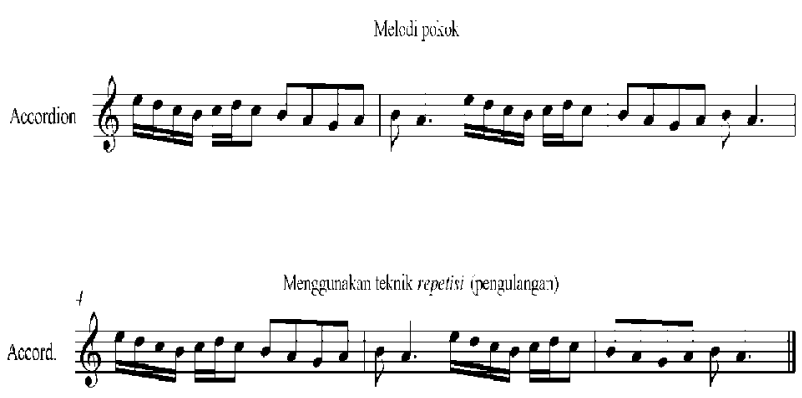

Ketenangan dan kenyamanan setelah beribadah tersebut ternyata masih bisa dipecahkan dengan hal-hal yang ada bersifat duniawi itulah yang penulis rasakan dan tuangkan kedalam bagian kedua karya Kala ini. Motif rebana dengan tempo cepat adalah pemecah dari suasana ketenangan dan kenyamanan tersebut. Pada bagian ini penulis sengaja menabrak bagian dari motif joget Melayu tersebut dengan maksud untuk memecah suasana tersebut. Setelah itu barulah masuk motif tabuhan Lampung lainnya yaitu tabuh sanak miwang di ejan yang sudah diaransemen dan sekaligus menjadi penutup bagian kedua pada garapan ini. Motif polyrhythmic sangat mendominasi pada bagian ini. Sukat yang diusung pada bagian ini adalah sukat 4/4 yang digabungkan dengan sukat 5/8. 
Sukat 4/4 dimainkan instrumen cetik, bonang, rebana dan xylophone dengan pola-pola tabuhan Lampung, sedangkan sukat 5/8 dimainkan instrumen drumset, electric bass, marimba, dan vibraphone.

\section{Bagian III}

Motif-motif permainan kombo band sangatlah dominan pada bagian ini seperti motif swing jazz, motif jungle, dan motif rock. Akan tetapi seluruh motif kombo band tesebut tetap dimasukkan unsur dari etnis Lampung dan Melayu. Pada perpindahan bagian II ke bagian III, penulis menggunakan sukat 7 dan sukat 9 sebelum masuk ke bagian selanjutnya. Kombo band pada bagian ini dijadikan pondasi dan latar belakang komposisi ini. Suasana yang ingin digambarkan adalah suasana modern yang ada di kota Bandar Lampung. Modern yang dimaksud lebih cenderung kepada musiknya, karena di kota Bandar Lampung ada fenomena bahwa musik etnis menjadi pilihan kedua bagi generasi muda. Menurut mereka musik band menjadi pilihan utama generasi muda yang ada di kota Bandar Lampung. Ketertarikan akan fenomena tersebut menjadi akar dari bagian tiga ini, ditambah lagi dengan perkembangan zaman hingga saat ini yang semakin lama semakin berubah dengan munculnya teknologi-teknologi yang sangat berpengaruh pesat khususnya di kota Bandar Lampung. Oleh karena itu, bagian tiga sengaja memadukan unsur-unsur Barat seperti motif swing jazz, jungle, dan rock dengan unsur-unsur etnis sebagai pengejawantahan berkembangnya fenomena musik Barat di Bandar Lampung yang diharapkan sejajar dengan perkembangan musik etnis. Pada bagian ini tangga nada yang digunakan menggunakan tangga nada minor dan minor dimayorkan dengan akord awal Am. Tempo yang dimainkan adalah tempo sedang dan semakin cepat dengan dinamika keras dan lembut. Pada bagian III ini penulis juga menggunakan teknik sekuen (pengulangan dari tingkat tinggi atau rendah). Bagian ini sekaligus menjadi bagian terakhir dari komposisi Kala

Teknik sekuens pada akhir dari bagian ini yang dimainkan secara unisono

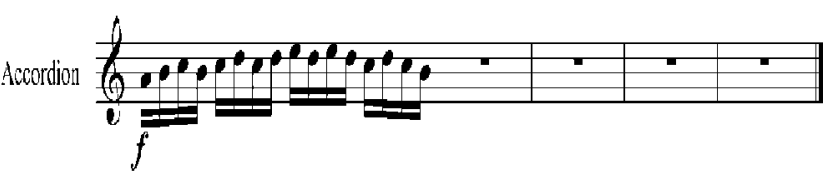

\section{Penutup}

Waktu, ketekunan, dan kesabaran merupakan kunci dalam menciptakan sebuah karya seni khususnya dibidang komposisi musik etnis. Membatasi ide di luar kemampuan diri sendiri adalah salah satu langkah untuk mempercepat proses penciptaan sebuah karya seni.

Kala adalah judul pada karya ini yang menurut bahasa Sanskerta berarti waktu. Kita mengetahui bahwa waktu selalu bergerak maju dan tidak akan pernah mundur, disetiap pergantian waktu selalu ada perkembangan dan perubahan yang terjadi khususnya perkembangan dan perubahan zaman. Perubahan pola pikir manusia sangat memicu terjadinya perkembangan zaman tersebut. Oleh karena itu dari zaman dahulu kala hingga saat ini selalu ada perubahan yang terjadi. Perwujudan perubahan zaman tersebut dituangkan ke dalam komposisi musik Etnis yang berjudul Kala.

Komposisi Kala merupakan salah satu komposisi musik etnis yang memadukan musik Barat dan musik etnis dan dituangkan dalam bentuk bahasa musikal dengan media ungkap instrumen perkusi dan melodis. Teknik permainan instrumen yang digunakan merupakan teknik pukulan perkusi yang penulis dapatkan selama menimba ilmu di Jurusan Etnomusikologi, FSP, ISI Yogyakarta. Penyajian komposisi Kala menggunakan instrumen perkusi etnis dan Barat. Namun, dalam ansambel musiknya ditambahkan instrumen melodis seperti Biola, Gambus, Akordion, dan electric bass.

\section{Kepustakaan}

Bukri, et al. 1978. Sejarah Daerah Lampung. Lampung: Departemen Pendidikan dan Kebudayaan Kantor Wilayah Provinsi Lampung.

Darmaprawira W. A., Sulasmi. 2002. WARNA: Teoridan Kreativitas Penggunaannya. Bandung: ITB.

Hawkins, Alma M. 1990. Creating Through Dance. Yogyakarta: Institut Seni Indonesia. 
Prier SJ, Karl Edmund. 1996. Ilmu Bentuk Musik. Yogyakarta: Pusat Musik Liturgi.

Smith, Jacquelin. 1985. Komposisi Tari: Sebuah Petunjuk Praktis Bagi Guru. Yogyakarta: IKALASTI.

Soekarno, Ari, ed. t.t. Buku Pintar Musik. Jakarta: INOVASI.

Suharsono dan Retnoningsih Ana. 2011. Kamus Bahasa Indonesia Lengkap. Semarang: Widya Karya.

\section{Video/Audio}

Tribuana. 2012. Dokumentasi video Penciptaan Musik Etnis III karya M. Yoga Supeno.

Dikhanglaya. 2011. Dokumentasi video Penciptaan Musik Etnis II karya M. Yoga Supeno. ouk Betino. 2012. Dokumentasi video tari karya Merlia Atika.

Betapuak-tapuak. 2009. Dokumentasi video tari karya Vianik.

Apocalypto. 2006. Film karya sutradara Mel Gibson.

Cetik on the street. 2012. Dokumentasi video karya Sanggar Kerti Bhuana Bandar Lampung.

The Dying Soul t.t Lagu Dream Theater Soundtrack film "Dead Note".

\section{Informan}

A. Barden Mogni (42 tahun). Pimpinan sanggar Radin Intan Bandar Lampung.

I Gusti Nyoman Arsana (45 tahun). Pimpinan sanggar Kerti Buana Bandar Lampung.

Novan Adi Putra (25 tahun). Seniman Lampung. 